\title{
The Zinc-finger factor Insm1 (IA-1) is essential for the development of pancreatic $\beta$ cells and intestinal endocrine cells
}

\author{
Mathias S. Gierl, ${ }^{1}$ Nikolaos Karoulias, ${ }^{1}$ Hagen Wende, Michael Strehle, and Carmen Birchmeier ${ }^{2}$ \\ Max-Delbrück-Center for Molecular Medicine, Berlin 13125, Germany
}

\begin{abstract}
The pancreatic and intestinal primordia contain epithelial progenitor cells that generate many cell types. During development, specific programs of gene expression restrict the developmental potential of such progenitors and promote their differentiation. The Insm1 (insulinoma-associated 1, IA-1) gene encodes a Zinc-finger factor that was discovered in an insulinoma cDNA library. We show that pancreatic and intestinal endocrine cells express Insm1 and require Insm1 for their development. In the pancreas of Insm1 mutant mice, endocrine precursors are formed, but only few insulin-positive $\beta$ cells are generated. Instead, endocrine precursor cells accumulate that express none of the pancreatic hormones. A similar change is observed in the development of intestine, where endocrine precursor cells are formed but do not differentiate correctly. A hallmark of endocrine cell differentiation is the accumulation of proteins that participate in secretion and vesicle transport, and we find many of the corresponding genes to be down-regulated in Insm1 mutant mice. Insm1 thus controls a gene expression program that comprises hormones and proteins of the secretory machinery. Our genetic analysis has revealed a key role of Insm1 in differentiation of pancreatic and intestinal endocrine cells.
\end{abstract}

[Keywords: Insm1; development; endocrine; intestine; mouse; pancreas]

Supplemental material is available at http://www.genesdev.org.

Received January 30, 2006; revised version accepted July 17, 2006.

Endocrine cells in the pancreas and intestine play key roles in nutritional homeostasis through the regulated synthesis and secretion of hormones and growth factors. The islets of Langerhans contain the four principal endocrine cell types of the pancreas, the $\alpha, \beta, \delta$, and PP cells, which produce the hormones glucagon, insulin, somatostatin, and pancreatic polypeptide (PP), respectively (Edlund 2002; Murtaugh and Melton 2003; Wilson et al. 2003). More recently, a fifth endocrine cell type was identified that expresses ghrelin (Prado et al. 2004). The role of $\beta$ cells is fundamental for energy homeostasis of the body, and dysfunction or loss of $\beta$ cells causes diabetes. Endocrine cells are also scattered in the epithelium of the intestine and stomach. These endocrine cells are heterogeneous, and they can be distinguished on the basis of ultrastructure or content of hormone(s) such as substance $\mathrm{P}$, secretin, cholecystokinin (CCK), neurotensin, somatostatin, serotonin and peptide YY (PYY) (Rindi et al. 2004). Interestingly, some basic similarities exist in

\footnotetext{
${ }^{1}$ These authors contributed equally to this work.

${ }^{2}$ Corresponding author.

E-MAIL cbirch@mdc-berlin.de; FAX 49-30-9406-3765.

Article is online at http://www.genesdev.org/cgi/doi/10.1101/gad.381806.
}

the molecular mechanisms that control the development of endocrine cells in the intestine and pancreas.

Pancreas development initiates morphologically with the formation of epithelial buds that protrude dorsally and ventrally from the foregut (at embryonic day 9.5 [E9.5] in mice) and later fuse to form the definitive pancreas. These primordia contain progenitor cells that are capable of generating all pancreatic cell types, the endocrine, exocrine, and duct cells (Gu et al. 2003). Specific programs of gene expression restrict the developmental potential of these progenitors and promote their differentiation into the distinct cell types. Significant efforts have been made to identify the mechanisms that control the specification and differentiation of pancreatic endocrine cells, particularly $\beta$ cells. Such knowledge may provide a basis for the generation of insulin-producing cells from endodermal or embryonic stem (ES) cells (Edlund 2002; Murtaugh and Melton 2003; Wilson et al. 2003). Mutations in genes encoding components of the Notch signaling pathway lead to a premature and exclusive differentiation of endocrine cells, and Notch signaling is, thus, essential to maintain the progenitor pool (Apelqvist et al. 1999; Jensen et al. 2000). The basic helix-loophelix (bHLH) transcription factors Ngn3 and NeuroD1 
are essential factors that control the endocrine fate. $\mathrm{Mu}$ tation of Ngn3 precludes the development of all endocrine cells in the pancreas, mutation of NeuroD 1 reduces their number, and the ectopic expression of Ngn3 or NeuroD 1 under the control of the $P d x 1$ promoter allows premature and ectopic differentiation of islet cells that mainly produce glucagon (Naya et al. 1997; Gradwohl et al. 2000; Schwitzgebel et al. 2000). Thus, these genes determine an endocrine fate in the pancreas, but the allocation and differentiation of the different cellular subtypes appear to be controlled by other genes. $\mathrm{Pax} 4$ promotes the specification of the $\beta$ - and $\delta$-cell fate, and suppresses the emergence of $\alpha$ cells. $N k \times 2.2$ and $N k x 6.1$ are both essential for $\beta$-cell differentiation: $N k \times 2.2$ activity is required to initiate $\beta$-cell differentiation, while Nkx6.1 acts downstream from Nkx2.2 (Sosa-Pineda et al. 1997; Sussel et al. 1998; Sander et al. 2000; Wang et al. 2004; Collombat et al. 2005). In addition to their roles in the early development of the pancreas, $P d x 1$ (IPF1), Isl1, $H n f 1 \alpha, H n f 1 \beta, H n f 4 \alpha$, or NeuroD 1 are also required for differentiation and maintenance of $\beta$ cells (Edlund 2002; Murtaugh and Melton 2003; Wilson et al. 2003). Heterozygous mutations of $P d x 1, H n f 1 \alpha, H n f 1 \beta, H n f 4 \alpha$, or NeuroD1 in humans cause maturity-onset diabetes of the young (MODY), and further genes that control $\beta$-cell development might correspond to susceptibility genes that contribute to the occurrence of diabetes (Bell and Polonsky 2001; Shih and Stoffel 2002; Habener et al. 2005).

The intestinal epithelium contains epithelial progenitors that generate endocrine cells, other secretory cells like goblet and paneth cells, as well as enterocytes. Notch signaling suppresses the development of intestinal endocrine cells, and mutations in genes that encode components of the Notch signaling cascade lead to the appearance of supernumerary entero-endocrine and other secretory cells (Jensen et al. 2000; Fre et al. 2005; van Es et al. 2005). The bHLH factor Math1 is an important regulator of entero-endocrine development, and mutation of Math1 precludes the differentiation of endocrine, goblet, and paneth cells (Yang et al. 2001). Gfi1 controls the allocation of subtypes of secretory cells; in Gfil mutant mice, supernumerary endocrine cells are formed at the expense of paneth and goblet cells (Shroyer et al. 2005). Furthermore, Ngn3 is required for the development of all endocrine cell types of the intestine, whereas NeuroD1, Pax4, and Pax6 are necessary for differentiation of subtypes of endocrine cells (Naya et al. 1997; Larsson et al. 1998; Jenny et al. 2002; Lee et al. 2002).

The Insulinoma-associated 1 (Insm1, IA-1) gene encodes a DNA-binding protein with five Zinc-finger domains and is conserved in evolution (Goto et al. 1992). The human Insm1 gene was first identified in a subtraction library from an insulinoma (Goto et al. 1992) and was subsequently found to be expressed in a large number of insulinomas and other neuroendocrine tumors, as well as in the developing pancreas and nervous system (Goto et al. 1992; Zhu et al. 2002; Breslin et al. 2003). Available biochemical evidence indicates that expres- sion of Insm1 is controlled by transcription factors of the bHLH family, and that Insm 1 acts as a transcriptional repressor (Breslin et al. 2002, 2003). The homologous genes in Drosophila and Caenorhabditis elegans-nerfin-1 and eg1-46, respectively-play essential roles in neuronal development (Wu et al. 2001; Kuzin et al. 2005). The developmental or physiological roles of Insm 1 in vertebrates and the genes controlled by the factor have not been determined. To characterize the function of Insm1, we have introduced a targeted mutation in mice. Analysis of the mutant mice demonstrates that, in Insm 1 mutant mice, only few insulin ${ }^{+} \beta$ cells are produced. Despite the fact that $\alpha$ cells are generated eventually in the correct proportion in Insm1 mutant mice, their differentiation appears to be delayed. In addition, we provide evidence that the differentiation program of pancreatic endocrine cells is not correctly established in Insm1 mutant mice, as reflected in the downregulation of genes that control hormone processing and secretion. Furthermore, the differentiation of endocrine cells of the intestine is impaired in Insm1 mutant mice. Our analysis indicates that, in the mutant pancreas and intestine, endocrine precursor cells are generated but are blocked in their differentiation. Insm1 thus plays a key role in differentiation of endocrine cells that derive from the endoderm.

\section{Results}

Insm 1 is expressed in the endocrine cells of the pancreas

Insm1 is a single exon gene that is located on mouse chromosome 2 . We introduced a targeted mutation into the gene by homologous recombination in ES cells. In the targeting vector, a lac $Z$ cassette was fused in-frame to the Insm 1 initiation codon and Insm1 coding sequences were deleted. In addition, the vector contained a neomycin resistance gene (self-excision neo cassette) (Bunting et al. 1999) and a sequence encoding fragment A of diphtheria toxin $(D T A)$ for positive and negative selection in ES cells (Fig. 1A; see also Materials and Methods). Targeted ES cells were selected, used to generate chimeras, and transmission of the mutant allele through the male germline excised the neo cassette (Fig. 1B). In the resulting $I n s m 1^{\text {lac } Z}$ allele, exogenous sequences (lac $Z$ and a single loxP site) stay behind to replace the Insm1 coding sequences, but noncoding Insm 1 sequences remain intact. Homozygous Insm $1^{\text {lacz }}$ mutant embryos generated by heterozygous matings were normal in size and well developed until E12.5. After E12.5, however, Insm $1^{\text {lacZ }} / \operatorname{Insm} 1^{\text {lacZ }}$ embryos were recovered at frequencies that were lower than the expected Mendelian ratios and, at birth, Insm $1^{\text {lacZ }} / \operatorname{Insm} 1^{\text {lacZ }}$ mice were apparently unable to breathe and died (for additional details see Materials and Methods).

Insm1 expression was previously reported in insulinexpressing pancreatic cell lines (Zhu et al. 2002). In situ hybridization analysis demonstrated Insm1 expression in the dorsal pancreatic primordium already at E9.5, and 


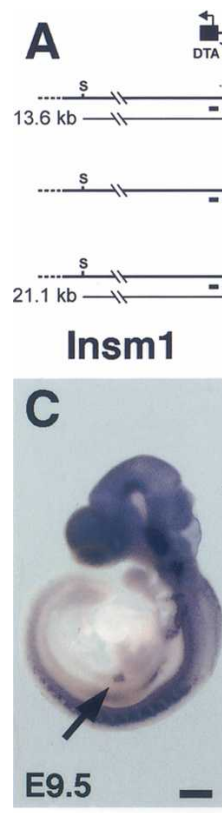

Ngn3 $\beta$-gal
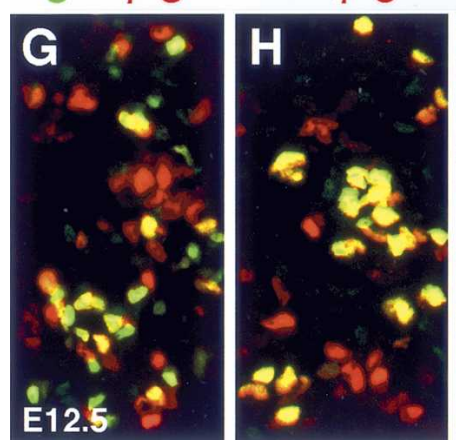

\section{Insm1}

Is|1 $\beta$-gal

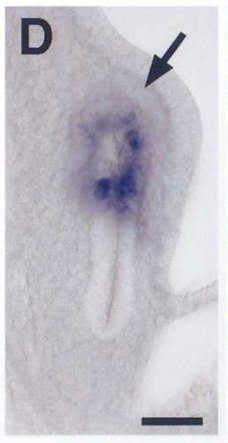

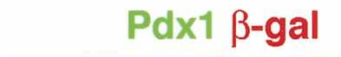

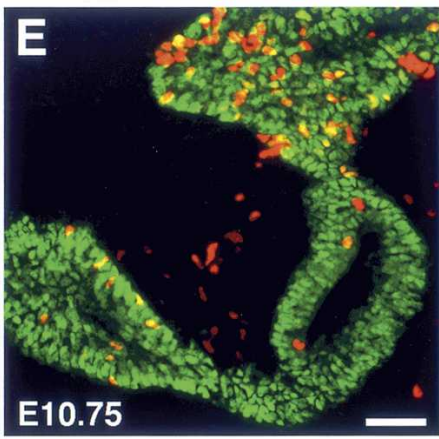

Hormones $\beta$-gal
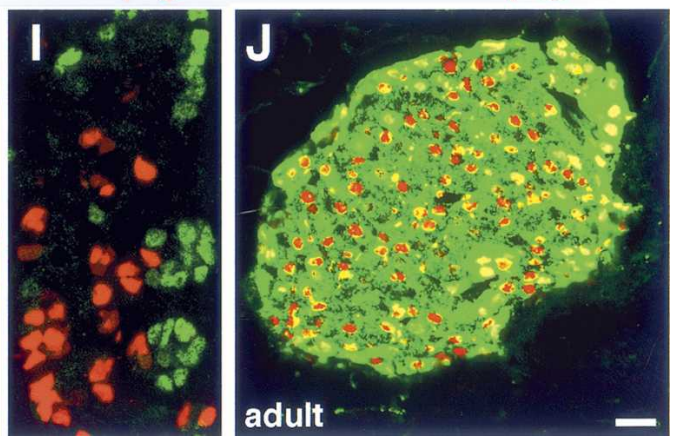

Figure 1. Generation of the $\operatorname{Insm} 1^{1 a c Z}$ mouse strain and Insm1 expression in the pancreas. (A) Schematic representation of the targeting vector, the wild-type Insm 1 locus, and the mutated Insm1 allele, before and after removal of the self-excision neomycin (cre, neo) cassette. Coding (red) and noncoding (pink) Insm1 sequences, NLS-lacZ (blue), DTA, the self-excision neomycin cassette, loxP (arrowhead), and $\mathrm{StuI}(\mathrm{S})$ restriction sites are depicted. Black lines indicate the predicted fragment sizes obtained after StuI digestion of genomic DNA. A black bar shows the $5^{\prime}$ sequence used as a probe for Southern analyses shown in $B$. (B) Southern blot analyses of StuI-digested genomic DNA from wildtype, Insm $1^{1 a c Z} /+$, and $\operatorname{Insm} 1^{\text {IacZ }} / \operatorname{Insm} 1^{1 a c Z}$ mice. $(C, D)$ In situ hybridization of E9.5 mouse embryos using an Insm1-specific probe; Insm1 is expressed in the dorsal pancreatic bud (arrows) and the developing central and peripheral nervous system. $(E, F)$ Immunohistological analysis of the developing pancreas of Insm $1^{1 a c Z} /+$ embryos at E10.75 using antibodies against $\beta$-galactosidase (red) and Pdx1 (green) $(E)$, and $\beta$-galactosidase (red), Pdx1 (green), and glucagon (blue) $(F)$. $(G-I)$ Immunohistological analysis of the dorsal pancreas of Insm $1^{1 a c Z} /+$ embryos at E12.5 using antibodies against $\beta$-galactosidase (red), and Ngn3 (green) $(G)$, Isl1 (green) $(H)$, and Ptfla (green) (I). Coexpression of $\beta$-galactosidase with proteins that mark endocrine cells (Is11, Ngn3, glucagon) is observed; in contrast, Ptfla is present in exocrine cells and is not coexpressed with $\beta$-galactosidase. $(J)$ Immunohistological analysis of the pancreas of adult Insm $1^{1 a c Z} /+$ mice using antibodies against $\beta$-galactosidase (red) and a mixture of antibodies directed against insulin, glucagon, PP, somatostatin, and ghrelin (green). Bars: $C, 400 \mu \mathrm{m} ; D, 50 \mu \mathrm{m} ; E, F, J, 20 \mu \mathrm{m}$.

in the dorsal and ventral primordium at E10.5 (Fig. 1C,D; Supplementary Fig. 1). In addition, widespread Insm1 expression was observed in the developing central and peripheral nervous system. Heterozygous $\operatorname{Insm} 1^{1 a c z} \mathrm{em}-$ bryos were used for a detailed analysis of Insm 1 expression in the developing pancreas. The epithelium of the dorsal and ventral pancreas is marked by $\mathrm{Pdx} 1$, and scattered cells that expressed $\beta$-galactosidase were present in the epithelium at E10.75; $\beta$-galactosidase ${ }^{+}$cells also coexpressed glucagon (Fig. 1E,F). Many $\beta$-galactosidase ${ }^{+}$ cells were also $\mathrm{Ngn}^{+}{ }^{+}, \mathrm{Is}_{1}{ }^{+}$, or $\mathrm{NeuroD}^{+}$, and coexpression of $\beta$-galactosidase and insulin or glucagon was also detectable at E12.5 (Figs. 1G,H, 2). This indicates that developing endocrine cells express $\beta$-galactosidase. Ptfla marks the exocrine lineage of the pancreas at E12.5 (Krapp et al. 1996), and was not coexpressed with $\beta$-galactosidase at E12.5 or subsequent stages (Figs. 1I, 3O). At E18.5, $\beta$-galactosidase ${ }^{+}$cells that coexpressed insulin, glucagon, somatostatin, $\mathrm{PP}$, and ghrelin were present in the pancreas of Insm1 $1^{\text {lacZ }} /+$ mice (see below). Insm1 transcripts are also present in adult pancreatic islets. Immunohistological analysis of adult $I n s m 1^{1 a c Z} /+$ mice in- dicated that the pancreatic hormones insulin, glucagon, somatostatin, PP, and ghrelin were coexpressed with $\beta$-galactosidase, indicating that all endocrine cell types maintain Insm1 expression (Fig. 1J; for further details on Insm1 expression, see Supplementary Fig. 1). The majority of $\beta$-galactosidase ${ }^{+}$cells express a pancreatic hormone at E18.5 (97.6\%) and in the adult (99.5\%). Thus, Insm 1 expression marks endocrine cells in the developing and adult pancreas.

Insm 1 is essential for the differentiation of pancreatic endocrine cells

We compared mice heterozygous and homozygous for the $\operatorname{Insm} 1^{\text {lacZ }}$ allele to assess the function of Insm 1 in the development of endocrine cells of the pancreas. In situ hybridization with $\mathrm{Pdxl}$ as a probe demonstrated that the epithelia of the dorsal and ventral pancreatic buds were similar in size in control and mutant mice at E12.5. We observed no change in the levels of Pdx1 protein or in the hybridization intensity at this stage (Supplementary Fig. 2). At E12.5 or E15.5, numbers of 
Gierl et al.
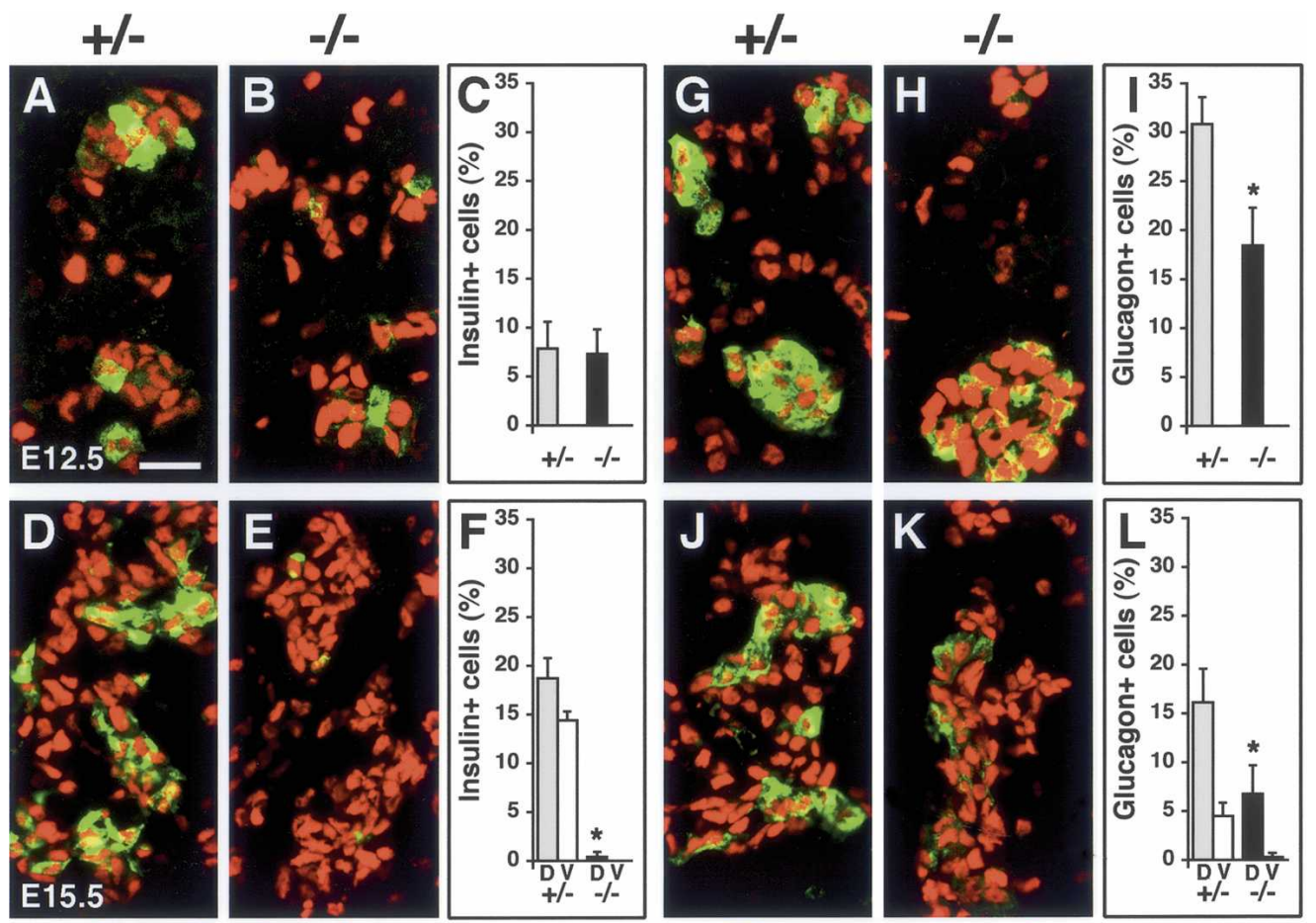

Insulin $\beta$-gal
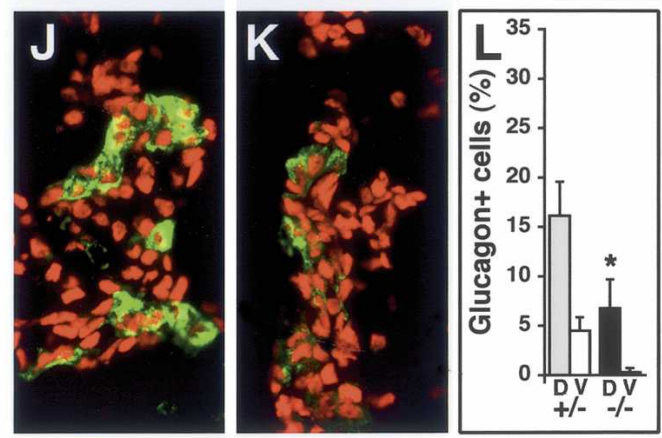

Glucagon $\beta$-gal

Figure 2. Impaired differentiation of $\alpha$ and $\beta$ cells in the pancreas of Insm 1 mutant mice. Immunohistological analysis of the developing dorsal pancreas of Insm $1^{1 a c Z} /+$ and Insm $1^{1 a c Z} / \operatorname{Insm} 1^{1 a c Z}$ mice at E12.5 $(A-C, G-I)$ and E15.5 $(D-F, J-L)$; the genotypes are indicated by $+/-$ and $-/-$, respectively. The antibodies used were directed against $\beta$-galactosidase (red) and insulin (green) $(A, B, D, E)$, and $\beta$-galactosidase (red) and glucagon (green) $(G, H, J, K)$. (C,I) Proportions of $\beta$-galactosidase ${ }^{+}$cells that express insulin $(C)$ and glucagon $(I)$ in the dorsal pancreas in Insm1 1acZ $/+$ (gray column) and in Insm1 1acZ/Insm1 1acZ (black column) mice at E12.5. $(F, L)$ Proportions of $\beta$-galactosidase ${ }^{+}$cells that express insulin $(F)$ or glucagon $(L)$ in the dorsal $(D)$ and ventral $(\mathrm{V})$ pancreas of $\operatorname{Insm} 1^{1 a c z} /+$ and $\operatorname{Insm} 1^{1 a c Z} /$ Insm $1^{\text {lacZ }}$ mice at E15.5. Asterisks indicate $p$-values of $<0.01$. Bar, $20 \mu \mathrm{m}$.

$\beta$-galactosidase ${ }^{+}$cells in the pancreas were similar, and a comparable proportion of $\beta$-galactosidase ${ }^{+}$cells coexpressed NeuroD1 or Isl1 in heterozygous and homozygous Insm $1^{1 a c Z}$ mutant mice (Supplementary Figs. 2, 3). This indicates that early pancreas development and the generation of the early endocrine precursor cells occurred correctly. However, we found profound changes in the subsequent differentiation of endocrine cells in the mutant mice. The first insulin ${ }^{+}$cells appear in the dorsal pancreas and coexpress $\beta$-galactosidase in $\operatorname{Insm} 1^{1 a c z} /+$ mice, and we detected similar numbers of insulin $^{+}$cells in the dorsal pancreas of heterozygous and homozygous Insm $1^{\text {lacZ }}$ mutant mice at E12.5 (Fig. 2AC). Many $\beta$ cells arise during the secondary transition, a wave of differentiation of endocrine cells that starts around E13. By E15.5, insulin ${ }^{+}$cells are abundant in the dorsal and ventral pancreas of $\operatorname{Insm} 1^{1 a c Z} /+$ mice, but we observed only rare insulin ${ }^{+}$cells in the dorsal and ventral pancreas of $\operatorname{Insm} 1^{\text {lac } Z} /$ Insm $1^{\text {lac } Z}$ mice (Fig. 2D-F). This indicates that $\beta$-cell neogenesis during the secondary transition does not occur. Glucagon ${ }^{+}$cells differentiate first in the dorsal pancreas, and glucagon ${ }^{+}$cells can be observed in the dorsal pancreas of $\operatorname{Insm} 1^{l a c z} /+$ and Insm $1^{\text {lacZ }} / \operatorname{Insm} 1^{\text {lacZ }}$ mice at E12.5. The number of glucagon $^{+}$cells was reduced at this stage in $\operatorname{Insm} 1^{\text {lacz }}$ /
Insm $1^{\text {lac } Z}$ mice, and the mutant $\alpha$ cells contained lower levels of the hormone than the $\alpha$ cells of control mice (Fig. 2G-I). At E15.5, numbers of glucagon ${ }^{+}$cells were reduced in the dorsal and ventral pancreas of $\operatorname{Insm} 1^{1 a c Z}$ / Insm $1^{\text {lac } Z}$ mice, and the mutant $\alpha$ cells contained reduced glucagon levels (Fig. 2J-L).

To further assess developing endocrine cells in the Insm1 mutant mice, we analyzed the expression of transcription factors known to control development and maintenance of pancreatic endocrine cells. $P d x 1$ is known to be essential for the differentiation of $\beta$ cells (Ahlgren et al. 1998; Sander et al. 2000; Holland et al. 2002; Fujitani et al. 2006). At E15.5, differentiating $\beta$ cells express high levels of $\mathrm{Pdx} 1$ protein; $\mathrm{Pdx} 1^{\text {high }}$ cells coexpress $\beta$-galactosidase in Insm $1^{1 a c z} /+$ animals. The number of $\mathrm{Pdx} 1^{\text {high }}$ cells was markedly reduced in the pancreas of $\operatorname{Insm} 1^{1 a c Z} / \operatorname{Insm} 1^{1 a c Z}$ mutants. In addition, $\mathrm{Pdx} 1$ is expressed at low levels in many cells of the pancreatic epithelium in control mice, and this was not changed in the Insm $1^{1 a c Z} / \operatorname{Insm} 1^{1 a c Z}$ mutants (Fig. 3A-F). MafA marks developing $\beta$ cells (Kataoka et al. 2002; Olbrot et al. 2002), and MafA protein was absent in Insm $1^{\text {lacZ }} /$ Insm $1^{\text {lac } Z}$ mice (Fig. $3 \mathrm{G}, \mathrm{H}$ ). In addition, the expression of Nkx2.2, Is11, and Nkx6.1 was analyzed. Whereas Nkx2.2 and Isl1 expression was similar in con- 

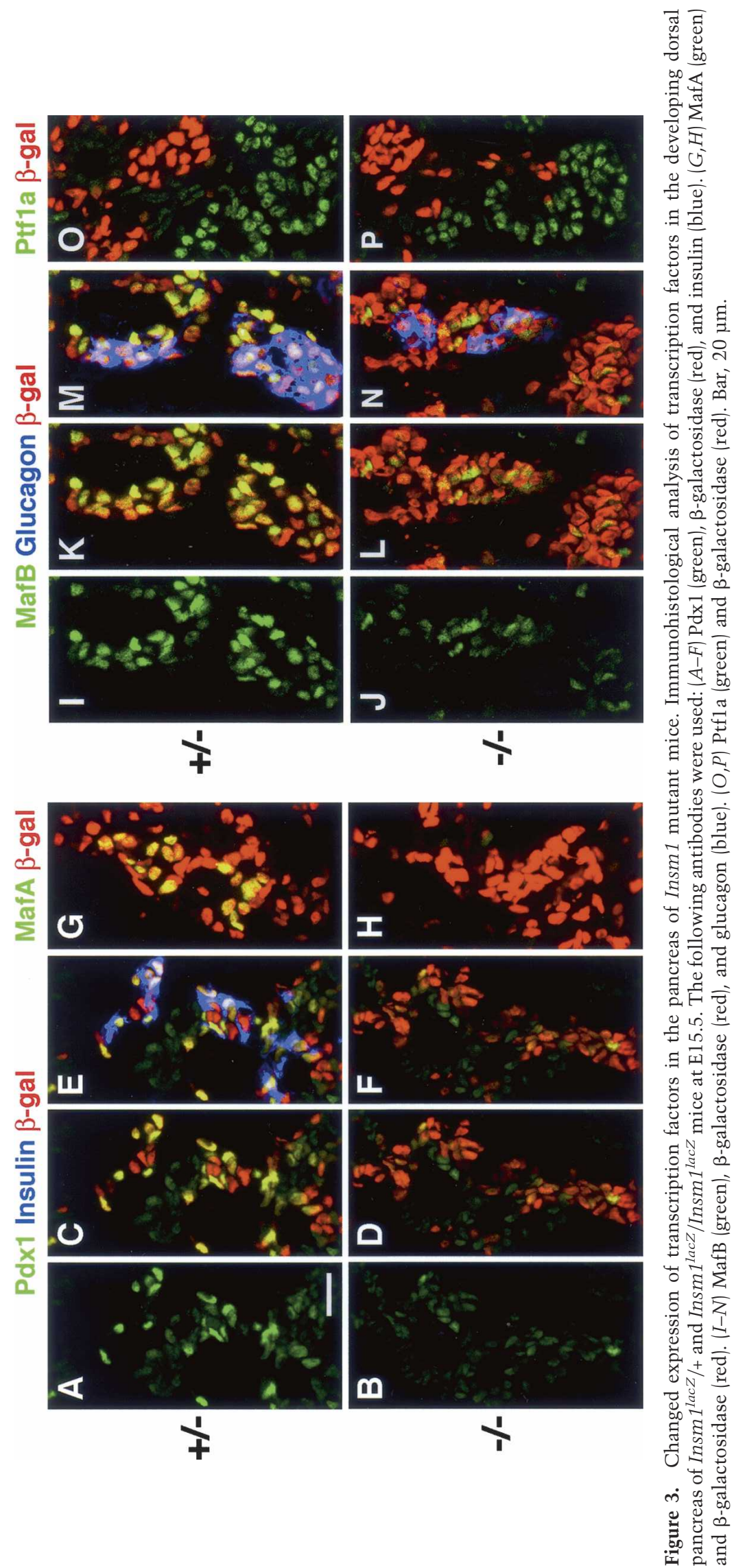


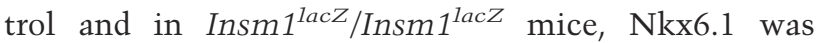
down-regulated (Supplementary Fig. 3). We conclude, therefore, that the expression of Pdx1, Nkx6.1, and MafA is altered in Insm1 mutant mice, indicating that the loss of Insm1 affects the transcriptional network that controls $\beta$-cell differentiation. We further assessed the development of the $\alpha$-cell lineage in the Insm $1^{\text {lacZ }}$ mutant mice. MafB is expressed in developing $\alpha$ cells of control mice (Artner et al. 2006) and was markedly reduced in the Insm $1^{\text {lacZ }} /$ Insm $1^{\text {lacZ }}$ mice (Fig. 3I-N). Arx and Pax6 are expressed in $\alpha$ cells and are important determinants in the development of this lineage (St-Onge et al. 1997; Collombat et al. 2003). Arx and Pax6 expression was also reduced (Table 1; Supplementary Fig. 3). Thus, the transcriptional network that controls $\alpha$-cell differentiation is also changed in the pancreas of Insm 1 mutant mice. In contrast, the exocrine lineage, as assessed by histology and immunohistological analysis of Ptfla and amylase expression, appeared unchanged in Insm 1 mutant mice (Figs. 3O,P, 4A,B; Supplementary Fig. 4). We conclude, therefore, that the Insm 1 mutation causes major deficits in the differentiation of pancreatic endocrine cells, but does not impair the exocrine lineage.

Histological analysis at E18.5 demonstrated the presence of islets of Langerhans in the pancreas of heterozygous and homozygous Insm $1^{\text {lac } Z}$ mutant mice. The islets in the Insm $1^{\text {lacZ }} / \operatorname{Insm} 1^{\text {lacZ }}$ mice, however, displayed an increased density of nuclei compared with control animals (Fig. 4A,B). We also counted the overall number of $\beta$-galactosidase ${ }^{+}$endocrine cells in the pancreas, and observed a $26 \%$ reduction at E18.5 in the mutant mice and no significant differences at E15.5 $1599 \pm 48$ cells per section and $444 \pm 47$ cells per section in heterozygous and homozygous Insm $1^{\text {lac } Z}$ mice at E18.5, respectively; $p$-value: $0.0079, n=3$ pancreata; $355 \pm 82$ cells per section and $281 \pm 69$ cells per section in heterozygous and homozygous Insm $1^{\text {lac } Z}$ mice at E15.5, respectively; $p$-value: $0.11, n=4$ pancreata). Apoptosis at late developmental stages appears to account for the reduced cell number, since $\mathrm{TUNEL}^{+}$cells in the pancreas at E18.5 were more abundant in homozygous than in heterozygous Insm $1^{\text {lac } Z}$ mutant mice (Supplementary Fig. 4). We counted the proportion of $\beta$-galactosidase $^{+}$cells that coexpressed insulin and observed a $92 \%$ reduction in the number of $\beta$ cells in $I n s m 1^{\text {lacz }}$ / Insm1 $1^{\text {lac } Z}$ mice at E18.5 (Fig. 4C-E). The proportion of $\beta$-galactosidase ${ }^{+}$cells that coexpressed somatostatin was also reduced in Insm $1^{\text {lacZ }} / \operatorname{Insm} 1^{\text {lacZ }}$ mice (Fig. 4F). The proportion of glucagon ${ }^{+}$cells was similar in $\operatorname{Insm} 1^{1 a c z} /+$ and Insm $1^{\text {lacZ }} /$ Insm $1^{\text {lacZ }}$ mice (Fig. 4G-I). However, mutant $\alpha$ cells contained less glucagon protein as assessed by the intensity of the immunohistological staining, and glucagon mRNA was down-regulated (Table 1). A delayed accumulation of glucagon protein might thus account for the reduction in the number of glucagon ${ }^{+}$cells observed at earlier stages. Thus, despite the fact that glucagon $^{+}$cells are produced in the correct proportion, their differentiation appears to be impaired. The proportions of $\beta$-galactosidase ${ }^{+}$cells that coexpressed PP or ghrelin were elevated and reduced, respectively, and the propor-
Table 1. Comparison of gene expression in the pancreas of heterozygous and homozygous Insm $1^{\text {lac }}$ mutant mice

\begin{tabular}{|c|c|c|c|}
\hline Symbol & Gene name & $\begin{array}{c}\text { Fold } \\
\text { change }\end{array}$ & $\begin{array}{l}\text { Change } \\
p \text {-value }\end{array}$ \\
\hline \multicolumn{4}{|c|}{ Hormones } \\
\hline Ins1 & Insulin I & -13.1 & $\star \star$ \\
\hline Ins2 & Insulin II & -13.5 & $\star \star$ \\
\hline Gcg & Glucagon & -4.1 & ** \\
\hline Ppy & PP & $\mathrm{p}, \mathrm{nc}$ & ns \\
\hline Ghrl & Ghrelin & $\mathrm{p}, \mathrm{nc}$ & ns \\
\hline Sst & Somatostatin & -2.5 & ** \\
\hline Npy & Neuropeptide Y & -8.3 & $\star \star$ \\
\hline \multicolumn{4}{|c|}{ Glucose metabolism } \\
\hline Slc2a2 & Glut2 & -2.9 & $\star \star$ \\
\hline G6pc2 & $\begin{array}{l}\text { Glucose-6-phosphatase, islet } \\
\text { specific }\end{array}$ & -19.4 & $\star \star$ \\
\hline \multicolumn{4}{|c|}{ Hormone processing and secretion } \\
\hline Pcsk1 & Prohormone convertase $1 / 3$ & -2.6 & ** \\
\hline Pcsk2 & Prohormone convertase 2 & -2.8 & ** \\
\hline Chga & Chromogranin A & -24.9 & $\star \star$ \\
\hline Chgb & Chromogranin B & -40.0 & ** \\
\hline Nnat & Neuronatin & -7.2 & $\star \star$ \\
\hline Resp18 & Regulated endocrine-specific protein 18 & -11.8 & $\star \star$ \\
\hline Rph3al & Rabphilin 3A-like & -2.1 & ** \\
\hline Scg2 & Secretogranin II & -33.3 & $\star \star$ \\
\hline Scg3 & Secretogranin III & -16.6 & $\star \star$ \\
\hline Scgn & Secretagogin & -13.6 & 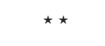 \\
\hline Sgne1 & Secretogranin V & -9.3 & $\star \star$ \\
\hline Snx5 & Sorting Nexin 5 & -2.5 & ** \\
\hline Syt14 & Synaptotagmin-like 4 & -4.4 & ** \\
\hline \multicolumn{4}{|c|}{ Transcription factors } \\
\hline Nkx2-2 & Nkx2.2 & $\mathrm{p}, \mathrm{nc}$ & ns \\
\hline Nkx6-1 & Nkx6.1 & -1.6 & $\star$ \\
\hline Pax4 & $\mathrm{Pax} 4$ & $\mathrm{p}, \mathrm{nc}$ & ns \\
\hline Pax6 & Pax6 & -2.4 & $\star \star$ \\
\hline Ipf1 & Pdx1 & -1.3 & $\star$ \\
\hline MafB & $\mathrm{MafB}$ & -1.9 & ** \\
\hline Arx & Arx & a & - \\
\hline \multicolumn{4}{|c|}{ Adhesion } \\
\hline $\mathrm{Cdh} 2$ & $\bar{N} c a d$ & $\mathrm{p}, \mathrm{nc}$ & ns \\
\hline \multicolumn{4}{|l|}{ Others } \\
\hline Iapp & Islet amyloid polypeptide & -2.1 & ** \\
\hline Aplp1 & Amyloid $\beta$ precursor-like protein 1 & -3.1 & $\star \star \star$ \\
\hline Gch1 & GTP cyclohydrolase & -2.7 & $\star \star$ \\
\hline Gja9 & Connexin 36 & -6.6 & ** \\
\hline Gng4 & GTP-binding protein $\gamma 4$ subunit & -4.9 & $\star \star$ \\
\hline Sez612 & Seizure-related 6 homolog-like 2 & -26.5 & ** \\
\hline Slc30a8 & 3 Solute carrier family 30 member 8 & -5.3 & $\star \star$ \\
\hline
\end{tabular}

Systematic analysis of gene expression in control and $\mathrm{Insm}^{-1^{-1}}$ mice using Affymetrix oligonucleotide microarrays. The average signal fold change and the change $p$-value as calculated by Affymetrix MAS 5.0 software are shown. Genes were selected based on a consistent and significant differential expression at E15.5 and E18.5. We also display data for those genes that were analyzed in this study by immunohistological analysis, in situ hybridization, or RT-PCR. Genes whose expression was analyzed by microarray analysis and by additional techniques are marked in bold. Genes whose expression was changed with a $p$-value $\leq 0.05$ and $\leq 0.001$ are marked by single or double asterisks, respectively. No probe sets exist for MafA on the MOE 430 2.0 GeneChip. (p) Present; (a) absent; (nc) not changed; (ns) not significant. 
tion of ghrelin ${ }^{+} /$glucagon $^{-}$cells was unchanged (Fig. 4JN). It should be noted that the numbers of $\gamma, \mathrm{PP}$, or $\varepsilon$ cells remained small in the islets of Insm 1 mutant mice, indicating that transdifferentiation of the mutant $\beta$ cells into one of these endocrine cell types did not occur.

In Insm $1^{\text {lacZ }} /+$ mice, the majority of $\beta$-galactosidase ${ }^{+}$ islet cells express one of the pancreatic hormones at
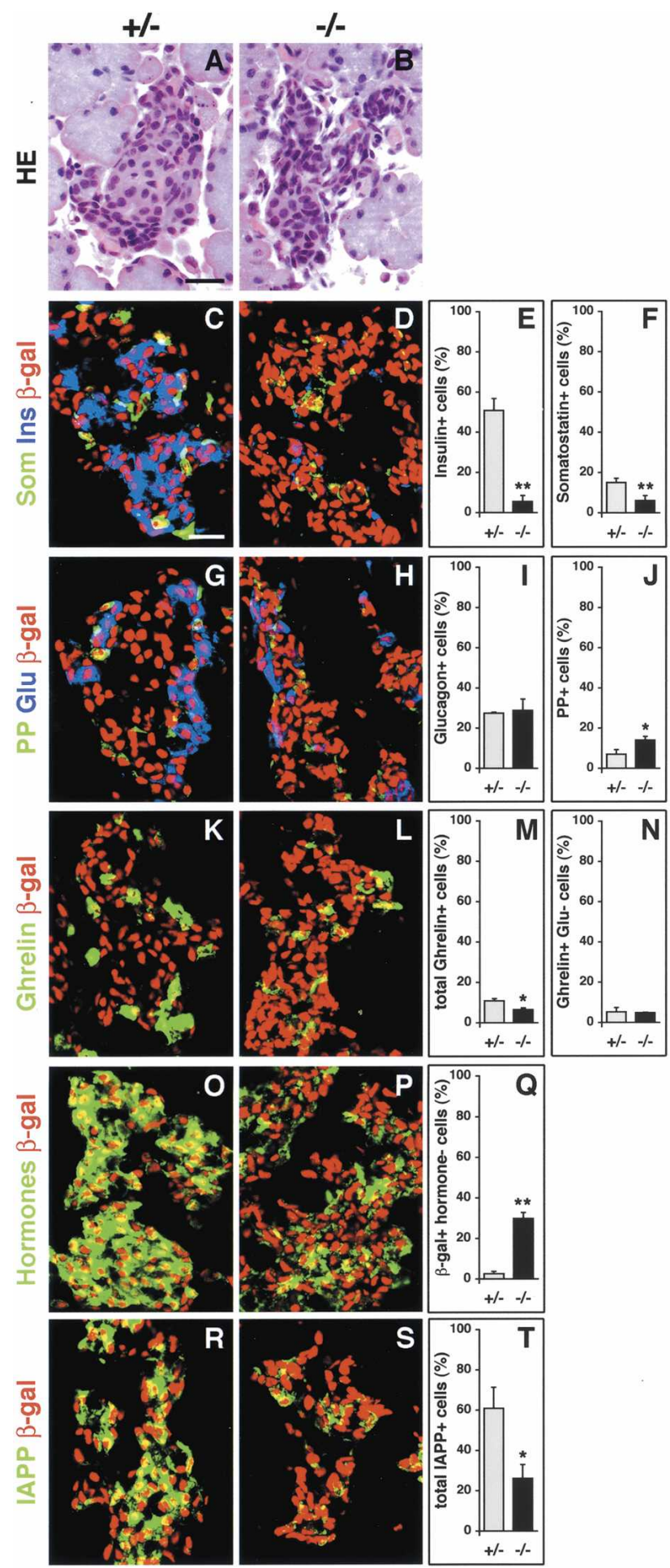

E18.5. This was, however, not observable in $\operatorname{Insm} 1^{\text {lacz/ }}$ Insm $1^{\text {lac } Z}$ mice, where many $\beta$-galactosidase ${ }^{+}$cells were present that expressed neither insulin, glucagon, somatostatin, PP, nor ghrelin (Fig. 4O-Q). Thus, other hormone-producing cell types do not form at the expense of $\beta$ cells in Insm1 $1^{\text {lacZ }} / \operatorname{Insm} 1^{\text {lacZ }}$ mice, indicating that $\beta$ cells arrest their differentiation. We investigated if other proteins typically present in endocrine cells were expressed correctly in Insm $1^{1 a c Z} / \operatorname{Insm} 1^{1 a c Z}$ mice. The glucose transporter 2 (Glut2) and the islet amyloid polypeptide (IAPP) are expressed in $\beta$ cells of control mice at E18.5. Cells that expressed Glut2 were rare in Insm $1^{\text {lacZ } / ~}$ Insm $1^{\text {lac } Z}$ mice, but many cells remained that expressed low levels of IAPP (Fig. 4R-T; Supplementary Fig. 4). Furthermore, the prohormone convertase $1 / 3$ as well as chromogranin A, which are expressed broadly in the pancreatic endocrine cell types, were significantly downregulated in the mutant mice. We analyzed the expression of these differentiation markers, specifically in glucagon $^{+}$cells, and found them down-regulated. Thus, mutant $\alpha$ cells expressed not only glucagon at lower levels, but also other differentiation markers like the prohormone convertase 2 and chromogranin A. In addition, changes in gene expression were also analyzed systematically using microarray analysis (Table 1). This indicated changes in transcript levels of pancreatic hormones, prohormone convertases, IAPP, and chromogranin $\mathrm{A}$ in the Insm 1 mutant mice, and thus verified the reduced levels of the corresponding proteins observed by immunohistological analysis. Interestingly, this systematic analysis revealed an additional set of significantly down-regulated transcripts, whose protein products function in vesicle transport and secretion-for instance, chromogranin $\mathrm{B}$; secretogranin II, III, and $\mathrm{V}$; sorting nexin 5; and synaptogamin-like protein 4 . We conclude, therefore, that terminal differentiation of pancreatic en-

Figure 4. Islet histology and hormone expression in the pancreas of Insm1 mutant mice. Histological and immunohistological analyses of the developing pancreas of $\operatorname{Insm} 1^{1 a c z} /+$ and Insm $1^{1 a c Z} / \operatorname{Insm} 1^{1 a c Z}$ mice at E18.5; the genotypes are indicated by $+/-$ and $-/-$, respectively. $(A, B)$ Hematoxylin/eosin (HE) staining of semi-thin sections of the pancreas. Islets are present in Insm $1^{1 a c Z} / \operatorname{Insm} 1^{1 a c Z}$ mice but display a changed nuclear density. Immunohistological analysis of the pancreas using antibodies directed against $\beta$-galactosidase (shown in red). In addition, antibodies directed against insulin (blue) and somatostatin (green) $(C, D)$, glucagon (blue) and PP (green) $(G, H)$, and ghrelin (green) $(K, L)$ were used. $(O, P)$ Immunohistology using rabbit anti-insulin, rabbit anti-glucagon, rabbit anti-somatostatin, rabbit anti-PP, and rabbit anti-ghrelin (green), and goat anti- $\beta$-galactosidase (red) antibodies simultaneously. Note that many $\beta$-galactosidase ${ }^{+}$cells exist in the pancreas of Insm1 $1^{1 a c Z}$ / Insm $1^{\text {lac } Z}$ embryos that do not express any of these five hormones. $(R, S)$ Immunohistological analysis of the pancreas using antibodies against $\beta$-galactosidase (shown in red) and IAPP (green). The proportions of the $\beta$-galactosidase ${ }^{+}$cells that express insulin $(E)$, somatostatin $(F)$, glucagon $(I)$, PP $(J)$, ghrelin $(M)$, ghrelin but not glucagon $(N)$, any of the five hormones $(Q)$, or IAPP $(T)$ are displayed. Single and double asterisks indicate $p$-values of $<0.01$ and $<0.001$, respectively. Bars, $20 \mu \mathrm{m}$. 
docrine cells is impaired in Insm 1 mutant mice, as reflected in a reduced expression of many genes involved in hormone secretion.

Insm 1 is essential for the differentiation of endocrine cells in the intestine

Insm 1 expression can also be detected in the intestine. In Insm $1^{1 a c Z} /+$ animals, $\beta$-galactosidase ${ }^{+}$cells are scattered in the intestinal epithelium and many of these coexpress NeuroD1 at E15.5 (arrows in Fig. 5A,B) or at E18.5 (Supplementary Fig. 5). Thus, these cells in the epithelium correspond to developing entero-endocrine cells. Additional $\beta$-galactosidase ${ }^{+}$cells are observed in a ring of
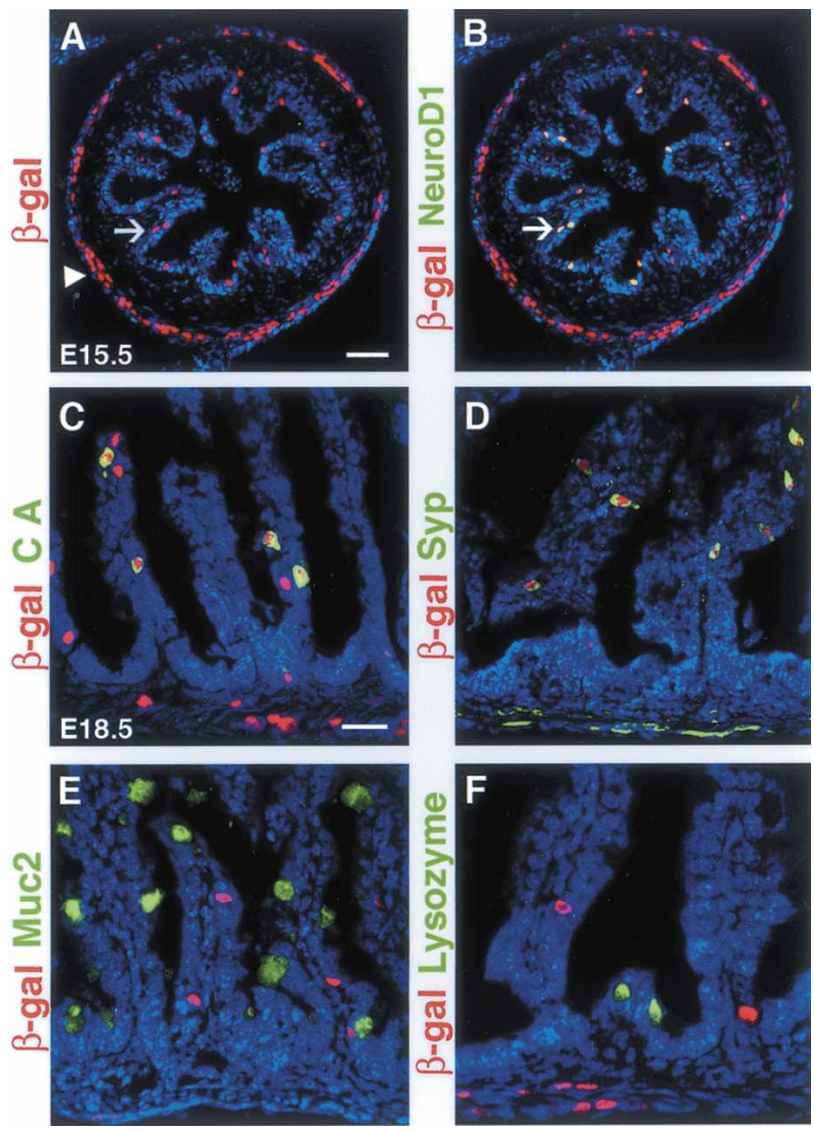

Figure 5. Insm 1 expression in the developing intestine. Immunohistological analysis of the developing intestine of Insm $1^{\text {lacZ }} /+$ mice at E15.5 $(A, B)$ and E18.5 $(C-F)$. $(A) \beta$-Galactosidase (red) was observed in the intestinal epithelium (arrow) and the enteric nervous system (arrowhead) of Insm $1^{1 a c Z} /+$ mice. $(B) \beta$-Galactosidase (red) is coexpressed with NeuroD1 (green) in entero-endocrine cells located in the intestinal epithelium (arrows), but not in the enteric nervous system (arrowhead); coexpressing cells appear yellow, an overlap of the red and green fluorescence. In the intestinal epithelium, all cells that contained chromogranin A (CA, green) $(C)$ or synaptophy$\sin ($ Syp, green $)(D)$ coexpressed $\beta$-galactosidase. In contrast, Mucin2 (Muc2, green) (E) or lysozyme (green) $(F)$ proteins were not observed in the $\beta$-galactosidase ${ }^{+}$(red) cells. Sections were counterstained with TOTO-3 (blue). Bars: $A, 50 \mu \mathrm{m} ; C, 20 \mu \mathrm{m}$. cells located in the enteric mesenchyme (arrowhead in Fig. 5A); the distribution of these indicates that they correspond to the developing enteric nervous system. Chromogranin A identifies the majority of entero-endocrine cells (Rindi et al. 2004), and many $\beta$-galactosidase ${ }^{+}$cells in the intestinal epithelium of $\operatorname{Insm} 1^{1 a c Z} /+$ animals coexpressed chromogranin A (Fig. 5C). Similarly, synaptophysin that marks entero-endocrine cells (Rindi et al. 2004; Sancho et al. 2004) is coexpressed with $\beta$-galactosidase in the intestinal epithelium (Fig. 5D). Mucin 2 or lysozyme, which mark paneth and goblet cells, respectively (Sancho et al. 2004), were however not coexpressed with $\beta$-galactosidase (Fig. 5E,F). Expression of Insm 1 persists in the adult intestine (Supplementary Fig. 1). We conclude that Insm1 is expressed in developing endocrine cells of the intestine.

We compared the development of endocrine cells in the intestine of mice heterozygous and homozygous for the Insm $1^{1 a c Z}$ allele. We observed no obvious difference in the overall number of $\beta$-galactosidase ${ }^{+}$cells in the intestinal epithelium of $\operatorname{Insm} 1^{\text {IacZ }} /+$ and $\operatorname{Insm} 1^{1 a c Z} / \operatorname{Insm} 1^{1 a c Z}$ mice at E15.5 or E18.5 (Fig. 6). At E15.5 or E18.5, the proportion of $\beta$-galactosidase ${ }^{+}$cells in the intestinal epithelium that coexpressed NeuroD1 was similar in heterozygous and homozygous Insm $1^{\text {lac }}$ mutant mice; expression of Ngn3, as assessed by in situ hybridization, was not affected (Supplementary Fig. 5). This indicates that endocrine precursor cells are formed correctly in Insm $1^{\text {lac } Z}$ mutant mice, but further analysis showed that their differentiation was altered. For instance, the number of cells that expressed chromogranin A was severely reduced and synaptophysin ${ }^{+}$cells were absent in the intestine of Insm $1^{\text {lacZ }} /$ Insm $1^{\text {lacZ }}$ animals (Fig. 6A-C; data not shown). Subtypes of entero-endocrine cells express a particular hormone, and subtypes that coexpress more than one hormone exist. Neurotensin is expressed by $30 \%$ of $\beta$-galactosidase ${ }^{+}$cells in the epithelium of the small intestine in $I n s m 1^{l a c Z} /+$ mice at E18.5. However, neurotensin ${ }^{+}$cells were not observed in Insm1 $1^{1 a c Z}$ / Insm $1^{\text {lac } Z}$ animals (Fig. 6D-F). Similarly, substance P is expressed by $40 \%$ of $\beta$-galactosidase ${ }^{+}$cells in the intestinal epithelium of $\operatorname{Insm} 1^{1 a c Z} /+$ animals, and was not present in the $\operatorname{Insm} 1^{\text {lacZ }} / \operatorname{Insm} 1^{\text {lacZ }}$ mice. The proportions of cells that coexpressed serotonin and $\beta$-galactosidase, or CCK and $\beta$-galactosidase, were reduced in the Insm $1^{\text {lacZ }} / \operatorname{Insm}^{\text {lacZ }}$ mice (Fig. 6J-O), and fewer PYY ${ }^{+}$ cells were observed (data not shown). In contrast, the proportion of $\beta$-galactosidase ${ }^{+}$cells that express secretin was similar in heterozygous and homozygous $\operatorname{Insm} 1^{\text {lac } Z}$ mutant mice (Fig. 6P-R). Alcian blue and periodic acidSchiff stainings indicated that paneth and goblet cells were produced correctly (Supplementary Fig. 5). We conclude, therefore, that Insm1 is essential for the expression of secretory vesicle proteins (chromogranin A, synaptophysin) in entero-endocrine cells. In addition, Insm 1 is required for the differentiation of particular subtypes of intestinal endocrine cells, which are either absent (substance $\mathrm{P}^{+}$or neurotensin ${ }^{+}$cells) or formed in reduced numbers (serotonin ${ }^{+}, \mathrm{CCK}^{+}$, or PYY ${ }^{+}$cells) in Insm $1 \mathrm{mu}-$ tant mice. 


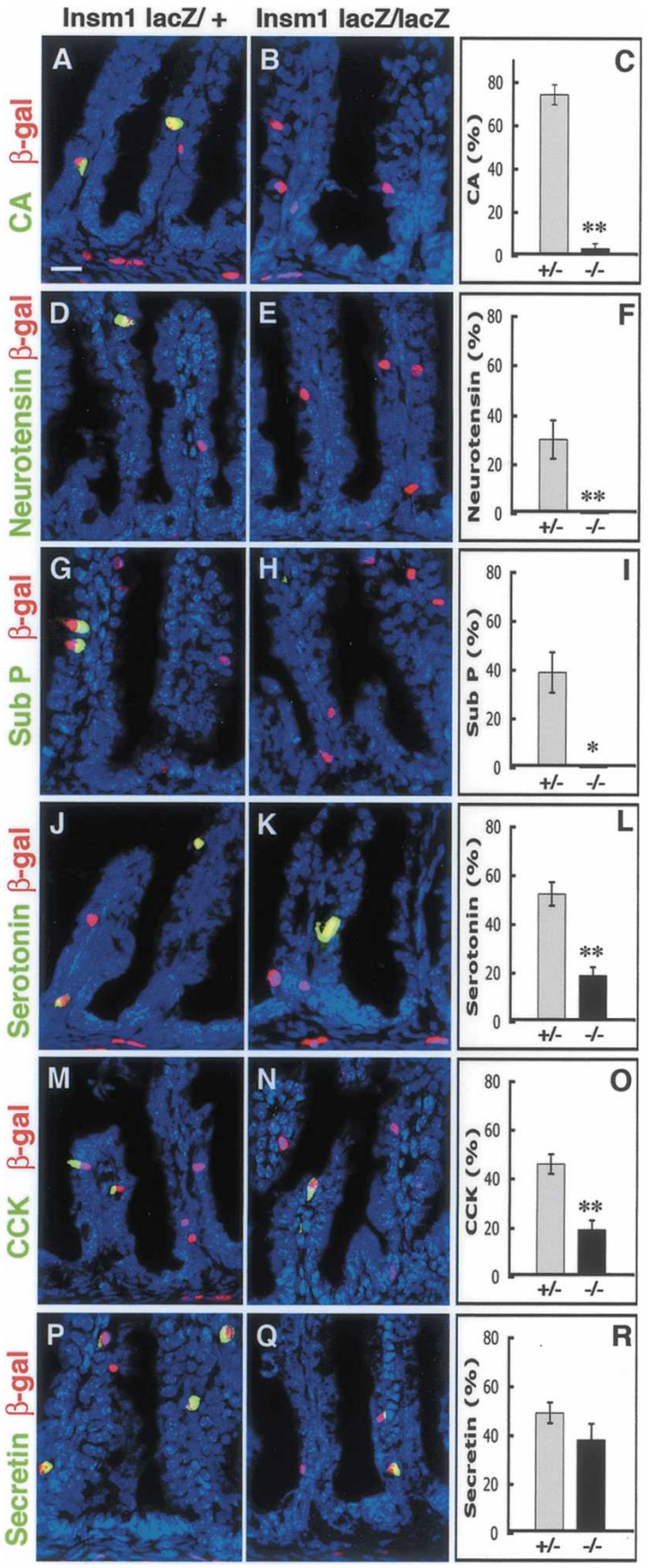

Figure 6. Insm 1 is essential for the differentiation of enteroendocrine cells. Immunohistological analysis of the intestine of Insm $1^{\text {lacZ }} /+$ and Insm $1^{1 a c Z} /$ Insm $1^{\text {lacZ }}$ mice at E18.5, using antibodies directed against chromogranin $\mathrm{A}(A, B)$, neurotensin $(D, E)$, substance $\mathrm{P}(G, H)$, serotonin $(J, K)$, CCK $(M, N)$, and secretin $(P, Q)$ (all shown in green); in addition, antibodies against $\beta$-galactosidase (shown in red) were used. The proportion of $\beta$-galactosidase ${ }^{+}$cells that express chromogranin A $(C)$, neurotensin $(F)$, substance $\mathrm{P}(I)$, serotonin $(L)$, CCK $(O)$, and secretin $(R)$ are displayed. Sections were counterstained with TOTO-3 (blue). Single and double asterisks indicate $p$-values of $<0.005$ and $<0.0001$, respectively. Bar, $20 \mu \mathrm{m}$.

\section{Discussion}

Insm1, a gene encoding a Zn-finger transcription factor, is expressed in endocrine cells of the pancreas and intestine. Our genetic analysis demonstrates the essential function of Insm 1 in the differentiation of pancreatic and intestinal endocrine cells. We show that, in the pancreas, $\beta$ cells are severely impaired in their differentiation. $\alpha$ Cells eventually form in a correct proportion, but their appearance is delayed and they express low levels of glucagon. Furthermore, intestinal endocrine cells do not develop correctly in Insm1 mutant mice. We observed a 25 -fold reduction in the numbers of chromogranin $\mathrm{A}^{+}$ cells, and particular subtypes of intestinal endocrine cells are absent or reduced in number. Notch signals and the transcription factors Ngn3, NeuroD1, Pax4, and Pax6 have previously been shown to control the development of endocrine cells in both, the pancreas and intestine, demonstrating that an overlapping set of genes directs the developmental program of these endodermal-derived endocrine lineages (Schonhoff et al. 2004; Habener et al. 2005). The phenotypes that we observed indicate that Insm 1 determines particular aspects of the differentiation program of endocrine cells and acts downstream from Notch and Ngn3, which promote an endocrine fate.

\section{The function of Insm1 in development of the endocrine pancreas}

The mature pancreas contains endocrine, exocrine, and ductal cells, which develop from a single progenitor cell type (Gu et al. 2003). A number of genes have been identified that specifically control the development of the endocrine lineage. Among those, Ngn3 promotes an endocrine fate, Pax4 and Arx determine whether an endocrine progenitor cell adopts an $\alpha$ - or $\beta$-cell fate, whereas Nkx2.2 and Nkx6.1 control the differentiation of pancreatic $\beta$ cells (Sussel et al. 1998; Gradwohl et al. 2000; Sander et al. 2000; Schwitzgebel et al. 2000; Prado et al. 2004). In addition to its early function in the development of the pancreas, Pdx1 is also essential for $\beta$-cell differentiation (Jonsson et al. 1994; Stoffers et al. 1997; Fujitani et al. 2006). Here we identified a novel factor, Insm1, to be essential for the development of the pancreatic $\beta$-cell lineage. The Insm1 gene was previously shown to be expressed in insulinomas, other endocrine tumors, and the pancreas (Goto et al. 1992; Zhu et al. 2002), but the function of this Zn-finger factor had not been assessed. Our genetic analysis using Insm 1 mutant mice demonstrates that Insm1 is indispensable for the correct differentiation of the $\beta$-cell lineage. In Insm $1 \mathrm{mu}$ tant mice, many $\beta$-cell precursors appear to be maintained, but these do not express any of the pancreatic hormones. This phenotype is not identical to the one observed in Nkx2.2, Pax4, and Nkx6.1 mutant mice: In Nkx2.2 or Pax4 mutant mice, ghrelin-expressing cells replace $\beta$ cells, whereas in Nkx6.1 mutants, $\beta$-cell neogenesis is defective, but undifferentiated endocrine cells do not accumulate (Sander et al. 2000; Prado et al. 2004). Immunohistological and microarray analyses reveal a 
down-regulation of Nkx6.1 and Pdx1 in the pancreas of Insm 1 mutant mice, indicating that Insm 1 affects the transcriptional network that determines $\beta$-cell differentiation.

In the Insm1 1acZ mutant allele, Insm1 coding sequences were replaced by lac $Z$. This allowed us to follow cells that express the allele in heterozygous and homozygous mutant mice. Our analysis indicates that Insm 1 is expressed in all endocrine cell types of developing and adult pancreatic islets; i.e., in $\alpha, \beta, \mathrm{PP}, \delta$, and $\varepsilon$ cells. In Insm 1 mutant mice, endocrine precursor cells were generated, as assessed by the expression of Is11, NeuroD1, and Ngn3, but their differentiation was impaired. The development of $\beta$ cells was most severely affected. In particular, we noted a massive reduction in the number of insulin ${ }^{+}$cells in Insm1 mutant mice, and many proteins present in $\beta$ cells of control mice (Glut2, IAPP, prohormone convertase $1 / 3$, chromogranin A) were strongly down-regulated. Furthermore, we did not observe an up-regulation of genes that would be indicative of a transdifferentiation of cells in the mutant pancreas and, in particular, other pancreatic endocrine cell types did not replace the mutant $\beta$ cells. The mutant $\beta$ cells retained, however, the expression of $\beta$-galactosidase and some expressed also IAPP at low levels, indicating that they keep the character of pancreatic endocrine cells, and we propose that they are arrested in their terminal differentiation. In addition, we observed changes in the proportions of endocrine cells that express somatostatin or PP in Insm $1^{1 a c Z}$ mutant mice. Lineage analysis has indicated that $\beta, \delta$, and PP cells derive from a common lineage (Herrera et al. 1994; Herrera 2000). Our data indicate, therefore, that the molecular networks that ensure that these endocrine cell types are formed in correct proportion are also affected by the Insm 1 mutation.

Not only $\beta$ cells require Insm 1 for differentiation; we also observed significant changes in the development of the $\alpha$-cell lineage. Analysis of the numbers of glucagon ${ }^{+}$ cells indicated that they were initially reduced (E12.5, E15.5), but eventually these cells were present in correct proportion (E18.5), indicating that the effects of Insm 1 on early and late $\alpha$ cells might be distinct. Nevertheless, the expression levels of glucagon in the mutant $\alpha$ cells remained low. Furthermore, other proteins (prohormone convertases $1 / 3$ and 2 , chromogranin A) that are expressed in many pancreatic endocrine cell types and are present in $\alpha$ and $\beta$ cells were markedly down-regulated in Insm 1 mutant mice. Thus, despite the fact that $\alpha$ cells form in a correct proportion, their terminal differentiation is impaired. By microarray analysis, we found additional genes that function in hormone maturation, secretion, and vesicle transport to be down-regulated in the pancreas of Insm1 mutant mice, indicating that Insm 1 controls a genetic program that allows pancreatic hormone production and secretion. It is possible that the expression of some of these genes is altered not only in $\alpha$ and $\beta$ cells, but also in the other subtypes of pancreatic endocrine cells. Available biochemical evidence indicates that Insm 1 acts as a transcriptional repressor. Members of the snail family of Zn-finger transcription factors are related to Insm1, display a similar overall domain structure-i.e., a "SNAG" domain and five Zn-fingers-and are known to act as transcriptional repressors (Grimes et al. 1996). However, in our microarray analysis, genes that were significantly and consistently upregulated at E15.5 and E18.5 were not observed in the mutant mice, raising the possibility that Insm 1 might also function as a transcriptional activator. It is noteworthy that immunohistological analysis had revealed aberrantly high levels of $\mathrm{N}$-cadherin in pancreatic islets of Insm1 mutant mice (Supplementary Fig. 4), but microarray analysis indicated no significant change in the level of the corresponding transcript. Changes in the turnover of $\mathrm{N}$-cadherin protein might be responsible for this and could contribute to the altered islet morphology in Insm1 mutant mice.

\section{The function of Insm 1 in the development of intestinal endocrine cells}

Our analysis of Insm1 mutant mice demonstrates that this factor is essential not only for development of pancreatic endocrine cells, but also for the differentiation of endocrine cells of the intestine. The intestinal epithelium contains secretory cells (endocrine, paneth, and goblet cells) and absorptive enterocytes, which all derive from multipotent epithelial stem cells (Cohn et al. 1991). This stem cell does not appear to produce directly intestinal endocrine cells but generates a series of intermediary cells that become further restricted in their developmental potential. Available evidence indicates that a committed progenitor exists that gives rise to all secretory cell types (Yang et al. 2001). This progenitor produces cells that generate either the paneth/goblet or the endocrine lineage (Shroyer et al. 2005). The endocrine precursor expresses $N g n 3$ and requires $N g n 3$ for its formation, whereas NeuroD1 functions downstream from $\mathrm{Ngn} 3$ to coordinate cell cycle exit and terminal differentiation (Mutoh et al. 1998; Jenny et al. 2002). Using the Insm $1^{\text {lac } Z}$ allele, we demonstrate here that Insm 1 is expressed in developing intestinal endocrine cells. The extensive coexpression of $\beta$-galactosidase and NeuroD1 at E15.5 indicates that Insm1 is expressed mainly in postmitotic cells destined to form the entero-endocrine lineage. Differentiated entero-endocrine cell types express chromogranin A and synaptophysin (Rindi et al. 2004; Sancho et al. 2004). $\beta$-Galactosidase is coexpressed with chromogranin A and synaptophysin in heterozygous Insm $1^{\text {lacZ }}$ animals, and the proportion of coexpressing cells increases as development proceeds. This indicates that $\beta$-galactosidase expression initiates prior to the differentiation of entero-endocrine cells and persists in the differentiating cells. In homozygous Insm $1^{1 a c Z}$ mutant mice, $\beta$-galactosidase ${ }^{+}$cells form in the intestinal epithelium and coexpress NeuroD1, demonstrating that entero-endocrine precursor cells are generated. However, the Insm1 mutation affected their further differentiation; i.e., the expression of hormones and of secretory vesicle proteins like chromogranin A and synaptophysin. Interestingly, chromogranin A expression was down- 
regulated in intestinal and pancreatic endocrine cells of Insm1 mutant mice, indicating that similarities in the gene expression program controlled by Insm 1 might exist in these two organs. We conclude that Insm1 controls endocrine differentiation in the intestine and pancreas and acts downstream from Notch and Ngn3 that specify the endocrine fate in both organs.

\section{Insm 1 and pancreatic $\beta$ cells}

Impaired function or loss of pancreatic $\beta$ cells cause diabetes, a prevalent human disease throughout the world. We demonstrate here that $\beta$-cell differentiation is arrested in Insm 1 mutant mice. Insm 1 mutant mice appear unable to breathe and die at birth, indicating that other, as-yet-uncharacterized phenotypes are present in these mice. The postnatal lethality has precluded the analysis of the consequences of the Insm1 mutation on nutritional homeostasis. Many genes that contribute to the occurrence of diabetes encode transcription factors that play key roles in development of pancreatic $\beta$ cells (Bell and Polonsky 2001; Shih and Stoffel 2002; Habener et al. 2005). Further studies are required to assess whether Insm1, beyond its role in $\beta$-cell differentiation, is also essential for the maintenance and the correct function of $\beta$ cells.

While this manuscript was under review, a study on Insm1 expression and function appeared in press (Mellitzer et al. 2006). This paper demonstrates that Insm 1 is not expressed in Ngn3 mutant mice, and provides evidence that Insm1 is a direct target gene regulated by Ngn3. Furthermore, after application of Insm1 morpholinos to cultured pancreatic tissue, the authors report a reduction in numbers of developing insulin ${ }^{+}$and glucagon $^{+}$cells, confirming, thus, our data obtained in genetically modified mice.

\section{Materials and methods}

\section{Generation of Insm1-null mice}

The 129/Sv mouse PAC clone RPCIP711L1640Q2 (Resource Center/Primary Database, http://www.rzpd.de) containing Insm1 was isolated from the RPCI-21 library (Osoegawa et al. 2000). A 14-kb DNA fragment containing the Insm1 gene was isolated by gap repair (Lee et al. 2001). Homologous recombination in bacteria (Lee et al. 2001) was used to fuse an NLS-lacZ cassette to the ATG of Insm1, to introduce the self-excision neo cassette (Bunting et al. 1999), and to delete the coding sequence of Insm1. In addition, the MC1-diphtheria toxin A (DTA) cassette was placed at the $5^{\prime}$ end of the vector and was used for negative selection. E14.1 ES cells (129/Ola) were electroporated, and colonies that had incorporated the targeting vector into their genome were selected by G418 and analyzed for homologous recombination by Southern blot analysis using $5^{\prime}$ and $3^{\prime}$ sequences that lie outside of the targeting vector, as well as lac $Z$ sequences as probes. We injected blastocysts and identified chimeras that transmitted the mutant Insm $1^{\text {lac } Z}$ gene by mating chimeras to C57BL/6 females. The mutant strain was subsequently expanded by mating Insm1 $1^{\text {lac } Z}$ males to C57BL/6 females. Routine genotyping was performed by PCR and, occa- sionally, genotypes were verified by Southern blot hybridization. Lines deriving from two independently targeted ES cells were established. One line was used for the characterization of Insm1 function, and the other for verification of the phenotype.

Embryos derived from heterozygous matings were isolated at different stages of development. Insm $1^{\text {lac } Z} / \operatorname{Insm} 1^{1 a c Z}$ embryos were observed at the expected Mendelian frequency at E12.5 and earlier stages, but were recovered at lower ratios subsequently. At E18.5, only four out of 76 mice $(5.2 \%)$ generated by heterozygous matings had an Insm $1^{\text {lacZ }} / \operatorname{Insm} 1^{\text {lac } Z}$ genotype, indicating that the majority of Insm $1^{\text {lac } Z} / \operatorname{Insm} 1^{1 a c Z}$ embryos died during the second half of gestation on the mixed 129/Ola and $\mathrm{C} 57 \mathrm{BL} / 6$ genetic background. Surviving $\operatorname{Insm} 1^{1 a c Z} / \operatorname{Insm} 1^{1 a c Z}$ mice on the 129/Ola and C57BL/6 background were apparently well developed and normal in size at E18.5. The Insm $1^{1 a c Z}$ allele was then crossed for two to three generations onto the CD1 out-bred strain. On such a mixed genetic background, the lethality was reduced, and 60 out of $451(13 \%)$ mice generated by heterozygous matings had an Insm $1^{\text {lacZ }} / \operatorname{Insm} 1^{\text {lacZ }}$ genotype at E18.5. Again, the surviving mice were apparently well developed and normal in size. We used animals of a mix of the CD1, 129/Ola, and C57BL/6 background to generate the homozygous mice used for the analysis presented here. In addition, we also compared the pancreas of Insm $1^{1 a c Z} / \operatorname{Insm} 1^{1 a c Z}$ and Insm $1^{1 a c Z} /+$ mice on the mixed 129/Ola and C57BL/6 background, and observed very few $\beta$ cells and a comparable number of $\alpha$ cells at E18.5 (see Supplementary Fig. 4). Regardless of the genetic background, homozygous Insm $1^{1 a c z}$ mice remained cyanotic-i.e., appeared to be unable to breathe-and died shortly after birth.

\section{In situ hybridization, histology, and immunohistology}

In situ hybridization and histological analysis of mouse embryos were performed as previously described (Britsch et al. 1998). A 510-base-pair (bp) fragment located in the 3' untranslated region (UTR) of the mouse Insm 1 gene was used to generate the RNA probe. For immunohistological analysis, tissue was dissected and fixed with $4 \%$ paraformaldehyde in phosphate buffer $(\mathrm{pH} 7.4)$ for $2 \mathrm{~h}$. Intestinal tissues were flushed gently with PBS prior to fixation. Antibody staining was performed on 10- to 12- $\mu \mathrm{m}$ cryosections, using the following antibodies: goat anti- $\beta$-galactosidase $(1: 1000$; Biogenesis), rabbit anti- $\beta$-galactosidase $(1: 10,000$; ICN Biochemical), rabbit antiglucagon (1:1000; ImmunoStar), guinea pig anti-glucagon (1:500; Linco), rabbit anti-insulin (1:1000; ImmunoStar), guinea pig anti-insulin (1:1000; Biogenesis), rabbit anti-PP (1:500; Chemicon), rabbit anti-somatostatin (1:500; DakoCytomation), rabbit anti-Pdx1 (1:500; Chemicon), goat anti-NeuroD1 (1:500; Santa Cruz), guinea pig anti-Isl1 (1:20,000; a gift from Tom Jessell, Columbia University, New York), guinea pig anti-NKX6.1 (1:500; a gift from Maike Sander, University of California at Irvine, Irvine, CA), rabbit anti-Arx (1:500; a gift from Ahmed Mansouri, Max Planck Institute for Biophysical Chemistry, Göttingen, Germany), guinea pig anti-MafA (1:20,000), rabbit anti-Ptfla (1:500; a gift from Helena Edlund, University of Umea, Umea, Sweden), rabbit anti-secretin (1:50; Abcam), rabbit anti-neurotensin (1:3000; Sigma), rabbit anti-lysozyme (1:500; DakoCytomation), rabbit anti-CCK (1:250; Biotrend), rabbit anti-PYY (1:6000; Biotrend), rabbit anti-chromogranin A (1:1000; ImmunoStar), rabbit anti-synaptophysin (Zymed), rabbit anti-serotonin $(1: 5000 ;$ Sigma), rabbit anti-substance $\mathrm{P}$ (1:1000; Zymed), rabbit anti-mucin 2 (1:5000; Santa Cruz Biotechnology), rabbit anti-neurogenin3 (1:2000; a gift from Michael German, University of California at San Francisco, San Francisco, CA), guinea pig anti-MafB $(1: 20,000)$, rabbit anti-ghrelin (1:2000; a gift from Cathrine Tomasetto, Institut National 
de la Santé et de la Recherche Médicale [INSERM], Strasbourg, France), goat anti-ghrelin (1:1000; Santa Cruz Biotechnology), rabbit anti-IAPP (1:1000; Progen), guinea pig anti-Nkx2.2 (1:4000; a gift from Beatriz Sosa-Pineda, St. Jude's Children's Hospital, Memphis, TN), rabbit anti-prohormone convertase $1 / 3$ (1:100; Chemicon), rabbit anti-prohormone convertase 2 (1:100; Chemicon), goat anti-Glut2 (1:1000; Santa Cruz Biotechnology), rabbit anti-N-Cadherin (1:100; Santa Cruz Biotechnology), rabbit anti-amylase (1:100; Santa Cruz Biotechnology), and secondary antibodies conjugated with Cy2, Cy3, or Cy5 (Jackson ImmunoResearch). Intestinal sections were counterstained with the nuclear dye TOTO-3 (1:10,000; Molecular Probes). Cell death was determined by TUNEL staining using an Apop-Tag fluorescein in situ apoptosis detection kit (Intergen). Fluorescence was imaged on a Zeiss LSM 5 Pascal confocal microscope, and images were processed in Adobe Photoshop.

\section{Cell counts}

To determine the proportion of $\beta$-galactosidase ${ }^{+}$cells that express a particular pancreatic hormone, we used images taken from sections that were stained for $\beta$-galactosidase as well as for one of the hormones (insulin, glucagon, somatostatin, PP, or ghrelin). Cells that expressed $\beta$-galactosidase and a particular hormone were counted on at least three sections obtained from three to four independent heterozygous and homozygous Insm $1^{\text {lac } Z}$ mice. To determine the proportion of $\beta$-galactosidase $^{+}$cells that coexpress each of the hormones, at least 300 $\beta$-galactosidase ${ }^{+}$cells were analyzed at E15.5 and E18.5, and at least $100 \beta$-galactosidase ${ }^{+}$cells were analyzed at E12.5. The overall number of $\beta$-galactosidase ${ }^{+}$cells was essentially determined as described (Collombat et al. 2005). The absolute numbers of $\beta$-galactosidase ${ }^{+}$cells and the proportion of hormone ${ }^{+}$ cells can be used to calculate the absolute numbers of the cells that express a particular hormone. A comparison of the calculated absolute numbers-for instance, of $\alpha$ and $\beta$ cells-shows a pronounced reduction of $\beta$ cells and similar numbers of $\alpha$ cells when heterozygous and homozygous $\operatorname{Insm} 1^{\text {lac } Z}$ mice were compared.

In the intestine, cells that coexpress $\beta$-galactosidase and various markers of endocrine cells were counted from sections obtained from three to four independent heterozygous and homozygous Insm $1^{1 a c Z}$ mice. To determine the proportion of $\beta$-galactosidase $^{+}$cells that coexpress hormones/proteins, at least 100 $\beta$-galactosidase ${ }^{+}$cells were analyzed. To determine the significance of the observed differences, a Student's $t$-test for a onetailed distribution and a two-sample unequal variance was applied.

\section{Microarray analysis}

Whole pancreata were collected in RNAlater (Ambion) from E15.5 and E18.5 wild-type and Insm $1^{1 a c Z} / \operatorname{Insm} 1^{1 a c Z}$ embryos and homogenized in Trizol (Invitrogen). RNA extraction, probe synthesis, and hybridization to Affymetrix MOE430 2.0 microarrays (Affymetrix) were performed according to the manufacturer's protocol. Further data processing and identification of differentially expressed genes were carried out in the R environment for statistical computing ( $\mathrm{R}$ Development Core Team 2005) using the Bioconductor base installation (Gentleman et al. 2004) and packages affyPLM, gcrma, and limma. Briefly, array quality was assessed with affyPLM, and data were normalized with gcrma. Probe sets with low variance of expression across all arrays were filtered out, and differentially expressed genes were identified using the empirical Bayes-moderated $t$-test implemented in the limma package. $P$-values associated with the $t$-statistics were adjusted using a false-discovery-rate approach to compensate for multiple testing. Genes were considered differentially expressed if the difference of their expression level had a $p$-value of $\leq 0.05$.

\section{Acknowledgments}

We thank Verena Sasse, Karin Gottschling, Petra Stallerow, and Claudia Päseler for expert technical assistance, and Walter Birchmeier, Alistair Garratt, and Thomas Müller for critically reading the manuscript. We gratefully acknowledge Tom Jessell (Is11), Maike Sander (Nkx6.1), Ahmed Mansouri (Arx), Helena Edlund (Ptf1a), Michael German (Ngn3), Cathrine Tomasetto (Ghrelin), and Beatriz Sosa-Pineda (Nkx2.2) for the indicated antibodies. We also thank Gérard Gradwohl (INSERM, Strasbourg, France), Mathias Treier (European Molecular Biology Laboratory [EMBL], Heidelberg, Germany), and Helena Edlund for providing us with a Ngn3 plasmid, the DTA cassette, and a $P d x 1$ plasmid.

\section{References}

Ahlgren, U., Jonsson, J., Jonsson, L., Simu, K., and Edlund, H. 1998. $\beta$-Cell-specific inactivation of the mouse Ipf $1 / \mathrm{Pdx} 1$ gene results in loss of the $\beta$-cell phenotype and maturity onset diabetes. Genes \& Dev. 12: 1763-1768.

Apelqvist, A., Li, H., Sommer, L., Beatus, P., Anderson, D.J., Honjo, T., Hrabe de Angelis, M., Lendahl, U., and Edlund, H. 1999. Notch signalling controls pancreatic cell differentiation. Nature 400: 877-881.

Artner, I., Le Lay, J., Hang, Y., Elghazi, L., Schisler, J.C., Henderson, E., Sosa-Pineda, B., and Stein, R. 2006. MafB: An activator of the glucagon gene expressed in developing islet $\alpha$ and $\beta$-cells. Diabetes 55: 297-304.

Bell, G.I. and Polonsky, K.S. 2001. Diabetes mellitus and genetically programmed defects in $\beta$-cell function. Nature 414: 788-791.

Breslin, M.B., Zhu, M., Notkins, A.L., and Lan, M.S. 2002. Neuroendocrine differentiation factor, IA-1, is a transcriptional repressor and contains a specific DNA-binding domain: Identification of consensus IA-1 binding sequence. Nucleic Acids Res. 30: 1038-1045.

Breslin, M.B., Zhu, M., and Lan, M.S. 2003. NeuroD1/E47 regulates the E-box element of a novel zinc finger transcription factor, IA-1, in developing nervous system. J. Biol. Chem. 278: 38991-38997.

Britsch, S., Li, L., Kirchhoff, S., Theuring, F., Brinkmann, V., Birchmeier, C., and Riethmacher, D. 1998. The ErbB2 and ErbB3 receptors and their ligand, neuregulin-1, are essential for development of the sympathetic nervous system. Genes \& Dev. 12: 1825-1836.

Bunting, M., Bernstein, K.E., Greer, J.M., Capecchi, M.R., and Thomas, K.R. 1999. Targeting genes for self-excision in the germ line. Genes \& Dev. 13: 1524-1528.

Cohn, S.M., Roth, K.A., Birkenmeier, E.H., and Gordon, J.I. 1991. Temporal and spatial patterns of transgene expression in aging adult mice provide insights about the origins, organization, and differentiation of the intestinal epithelium. Proc. Natl. Acad. Sci. 88: 1034-1038.

Collombat, P., Mansouri, A., Hecksher-Sorensen, J., Serup, P., Krull, J., Gradwohl, G., and Gruss, P. 2003. Opposing actions of Arx and Pax4 in endocrine pancreas development. Genes \& Dev. 17: 2591-2603.

Collombat, P., Hecksher-Sorensen, J., Broccoli, V., Krull, J., 
Ponte, I., Mundiger, T., Smith, J., Gruss, P., Serup, P., and Mansouri, A. 2005. The simultaneous loss of Arx and Pax4 genes promotes a somatostatin-producing cell fate specification at the expense of the $\alpha$ - and $\beta$-cell lineages in the mouse endocrine pancreas. Development 132: 2969-2980.

Edlund, H. 2002. Pancreatic organogenesis-Developmental mechanisms and implications for therapy. Nat. Rev. Genet. 3: 524-532.

Fre, S., Huyghe, M., Mourikis, P., Robine, S., Louvard, D., and Artavanis-Tsakonas, S. 2005. Notch signals control the fate of immature progenitor cells in the intestine. Nature 435: 964-968.

Fujitani, Y., Fujitani, S., Boyer, D.F., Gannon, M., Kawaguchi, Y., Ray, M., Shiota, M., Stein, R.W., Magnuson, M.A., and Wright, C.V. 2006. Targeted deletion of a cis-regulatory region reveals differential gene dosage requirements for Pdx1 in foregut organ differentiation and pancreas formation. Genes \& Dev. 20: 253-266.

Gentleman, R.C., Carey, V.J., Bates, D.M., Bolstad, B., Dettling, M., Dudoit, S., Ellis, B., Gautier, L., Ge, Y., Gentry, J., et al. 2004. Bioconductor: Open software development for computational biology and bioinformatics. Genome Biol. 5: R80.

Goto, Y., De Silva, M.G., Toscani, A., Prabhakar, B.S., Notkins, A.L., and Lan, M.S. 1992. A novel human insulinoma-associated cDNA, IA-1, encodes a protein with 'zinc-finger' DNA-binding motifs. J. Biol. Chem. 267: 15252-15257.

Gradwohl, G., Dierich, A., LeMeur, M., and Guillemot, F. 2000. neurogenin 3 is required for the development of the four endocrine cell lineages of the pancreas. Proc. Natl. Acad. Sci. 97: $1607-1611$

Grimes, H.L., Chan, T.O., Zweidler-McKay, P.A., Tong, B., and Tsichlis, P.N. 1996. The Gfi-1 proto-oncoprotein contains a novel transcriptional repressor domain, SNAG, and inhibits G1 arrest induced by interleukin-2 withdrawal. Mol. Cell. Biol. 16: 6263-6272.

Gu, G., Brown, J.R., and Melton, D.A. 2003. Direct lineage tracing reveals the ontogeny of pancreatic cell fates during mouse embryogenesis. Mech. Dev. 120: 35-43.

Habener, J.F., Kemp, D.M., and Thomas, M.K. 2005. Minireview: Transcriptional regulation in pancreatic development. Endocrinology 146: 1025-1034.

Herrera, P.L. 2000. Adult insulin- and glucagon-producing cells differentiate from two independent cell lineages. Development 127: 2317-2322.

Herrera, P.L., Huarte, J., Zufferey, R., Nichols, A., Mermillod, B., Philippe, J., Muniesa, P., Sanvito, F., Orci, L., and Vassalli, J.D. 1994. Ablation of islet endocrine cells by targeted expression of hormone-promoter-driven toxigenes. Proc. Natl. Acad. Sci. 91: 12999-13003.

Holland, A.M., Hale, M.A., Kagami, H., Hammer, R.E., and MacDonald, R.J. 2002. Experimental control of pancreatic development and maintenance. Proc. Natl. Acad. Sci. 99: 12236-12241.

Jenny, M., Uhl, C., Roche, C., Duluc, I., Guillermin, V., Guillemot, F., Jensen, J., Kedinger, M., and Gradwohl, G. 2002. Neurogenin 3 is differentially required for endocrine cell fate specification in the intestinal and gastric epithelium. EMBO J. 21: 6338-6347.

Jensen, J., Pedersen, E.E., Galante, P., Hald, J., Heller, R.S., Ishibashi, M., Kageyama, R., Guillemot, F., Serup, P., and Madsen, O.D. 2000. Control of endodermal endocrine development by Hes-1. Nat. Genet. 24: 36-44.

Jonsson, J., Carlsson, L., Edlund, T., and Edlund, H. 1994. Insulin-promoter-factor 1 is required for pancreas development in mice. Nature 371: 606-609.

Kataoka, K., Han, S.I., Shioda, S., Hirai, M., Nishizawa, M., and
Handa, H. 2002. MafA is a glucose-regulated and pancreatic $\beta$-cell-specific transcriptional activator for the insulin gene. J. Biol. Chem. 277: 49903-49910.

Krapp, A., Knofler, M., Frutiger, S., Hughes, G.J., Hagenbuchle, O., and Wellauer, P.K. 1996. The p48 DNA-binding subunit of transcription factor PTF1 is a new exocrine pancreas-specific basic helix-loop-helix protein. EMBO J. 15: 4317-4329.

Kuzin, A., Brody, T., Moore, A.W., and Odenwald, W.F. 2005. Nerfin-1 is required for early axon guidance decisions in the developing Drosophila CNS. Dev. Biol. 277: 347-365.

Larsson, L.I., St-Onge, L., Hougaard, D.M., Sosa-Pineda, B., and Gruss, P. 1998. Pax 4 and 6 regulate gastrointestinal endocrine cell development. Mech. Dev. 79: 153-159.

Lee, E.C., Yu, D., Martinez de Velasco, J., Tessarollo, L., Swing, D.A., Court, D.L., Jenkins, N.A., and Copeland, N.G. 2001. A highly efficient Escherichia coli-based chromosome engineering system adapted for recombinogenic targeting and subcloning of BAC DNA. Genomics 73: 56-65.

Lee, C.S., Perreault, N., Brestelli, J.E., and Kaestner, K.H. 2002. Neurogenin 3 is essential for the proper specification of gastric enteroendocrine cells and the maintenance of gastric epithelial cell identity. Genes \& Dev. 16: 1488-1497.

Mellitzer, G., Bonne, S., Luco, R.F., Van De Casteele, M., LenneSamuel, N., Collombat, P., Mansouri, A., Lee, J., Lan, M., Pipeleers, D., et al. 2006. IA1 is NGN3-dependent and essential for differentiation of the endocrine pancreas. $E M B O J$. 25: 1344-1352.

Murtaugh, L.C. and Melton, D.A. 2003. Genes, signals, and lineages in pancreas development. Annu. Rev. Cell Dev. Biol. 19: 71-89.

Mutoh, H., Naya, F.J., Tsai, M.J., and Leiter, A.B. 1998. The basic helix-loop-helix protein BETA2 interacts with p300 to coordinate differentiation of secretin-expressing enteroendocrine cells. Genes \& Dev. 12: 820-830.

Naya, F.J., Huang, H.P., Qiu, Y., Mutoh, H., DeMayo, F.J., Leiter, A.B., and Tsai, M.J. 1997. Diabetes, defective pancreatic morphogenesis, and abnormal enteroendocrine differentiation in BETA2/neuroD-deficient mice. Genes \& Dev. 11: 2323-2334.

Olbrot, M., Rud, J., Moss, L.G., and Sharma, A. 2002. Identification of $\beta$-cell-specific insulin gene transcription factor RIPE3b1 as mammalian MafA. Proc. Natl. Acad. Sci. 99: 6737-6742.

Osoegawa, K., Tateno, M., Woon, P.Y., Frengen, E., Mammoser, A.G., Catanese, J.J., Hayashizaki, Y., and de Jong, P.J. 2000. Bacterial artificial chromosome libraries for mouse sequencing and functional analysis. Genome Res. 10: 116-128.

Prado, C.L., Pugh-Bernard, A.E., Elghazi, L., Sosa-Pineda, B., and Sussel, L. 2004. Ghrelin cells replace insulin-producing $\beta$ cells in two mouse models of pancreas development. Proc. Natl. Acad. Sci. 101: 2924-2929.

R Development Core Team. 2005. R: A language and environment for statistical computing. R Foundation for Statistical Computing, Vienna, Austria.

Rindi, G., Leiter, A.B., Kopin, A.S., Bordi, C., and Solcia, E. 2004 The 'normal' endocrine cell of the gut: Changing concepts and new evidences. Ann. N. Y. Acad. Sci. 1014: 1-12.

Sancho, E., Batlle, E., and Clevers, H. 2004. Signaling pathways in intestinal development and cancer. Annu. Rev. Cell Dev. Biol. 20: 695-723.

Sander, M., Sussel, L., Conners, J., Scheel, D., Kalamaras, J., Dela Cruz, F., Schwitzgebel, V., Hayes-Jordan, A., and German, M. 2000. Homeobox gene Nkx6.1 lies downstream of $N k x 2.2$ in the major pathway of $\beta$-cell formation in the pancreas. Development 127: 5533-5540.

Schonhoff, S.E., Giel-Moloney, M., and Leiter, A.B. 2004. 
Gierl et al.

Minireview: Development and differentiation of gut endocrine cells. Endocrinology 145: 2639-2644.

Schwitzgebel, V.M., Scheel, D.W., Conners, J.R., Kalamaras, J., Lee, J.E., Anderson, D.J., Sussel, L., Johnson, J.D., and German, M.S. 2000. Expression of neurogenin3 reveals an islet cell precursor population in the pancreas. Development 127: 3533-3542.

Shih, D.Q. and Stoffel, M. 2002. Molecular etiologies of MODY and other early-onset forms of diabetes. Curr. Diab. Rep. 2: $125-134$.

Shroyer, N.F., Wallis, D., Venken, K.J., Bellen, H.J., and Zoghbi, H.Y. 2005. Gfil functions downstream of Math1 to control intestinal secretory cell subtype allocation and differentiation. Genes \& Dev. 19: 2412-2417.

Sosa-Pineda, B., Chowdhury, K., Torres, M., Oliver, G., and Gruss, P. 1997. The Pax4 gene is essential for differentiation of insulin-producing $\beta$ cells in the mammalian pancreas. $\mathrm{Na}$ ture 386: 399-402.

Stoffers, D.A., Ferrer, J., Clarke, W.L., and Habener, J.F. 1997. Early-onset type-II diabetes mellitus (MODY4) linked to IPF1. Nat. Genet. 17: 138-139.

St-Onge, L., Sosa-Pineda, B., Chowdhury, K., Mansouri, A., and Gruss, P. 1997. Pax6 is required for differentiation of glucagon-producing $\alpha$-cells in mouse pancreas. Nature 387: $406-$ 409.

Sussel, L., Kalamaras, J., Hartigan-O'Connor, D.J., Meneses, J.J., Pedersen, R.A., Rubenstein, J.L., and German, M.S. 1998. Mice lacking the homeodomain transcription factor Nkx2.2 have diabetes due to arrested differentiation of pancreatic $\beta$ cells. Development 125: 2213-2221.

van Es, J.H., van Gijn, M.E., Riccio, O., van den Born, M., Vooijs, M., Begthel, H., Cozijnsen, M., Robine, S., Winton, D.J., Radtke, F., et al. 2005. Notch $/ \gamma$-secretase inhibition turns proliferative cells in intestinal crypts and adenomas into goblet cells. Nature 435: 959-963.

Wang, J., Elghazi, L., Parker, S.E., Kizilocak, H., Asano, M., Sussel, L., and Sosa-Pineda, B. 2004. The concerted activities of Pax4 and Nkx2.2 are essential to initiate pancreatic $\beta$-cell differentiation. Dev. Biol. 266: 178-189.

Wilson, M.E., Scheel, D., and German, M.S. 2003. Gene expression cascades in pancreatic development. Mech. Dev. 120: 65-80.

Wu, J., Duggan, A., and Chalfie, M. 2001. Inhibition of touch cell fate by egl-44 and egl-46 in C. elegans. Genes \& Dev. 15: 789-802.

Yang, Q., Bermingham, N.A., Finegold, M.J., and Zoghbi, H.Y. 2001. Requirement of Math1 for secretory cell lineage commitment in the mouse intestine. Science 294: 2155-2158.

Zhu, M., Breslin, M.B., and Lan, M.S. 2002. Expression of a novel zinc-finger cDNA, IA-1, is associated with rat AR42J cells differentiation into insulin-positive cells. Pancreas 24: 139-145. 


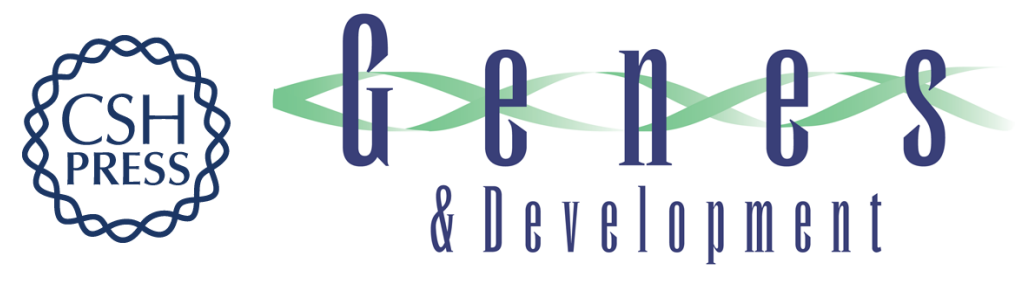

\section{The Zinc-finger factor Insm1 (IA-1) is essential for the development of pancreatic $\beta$ cells and intestinal endocrine cells}

Mathias S. Gierl, Nikolaos Karoulias, Hagen Wende, et al.

Genes Dev. 2006, 20:

Access the most recent version at doi:10.1101/gad.381806

Supplemental http://genesdev.cshlp.org/content/suppl/2006/09/05/20.17.2465.DC1
Material

References This article cites 55 articles, 29 of which can be accessed free at: http://genesdev.cshlp.org/content/20/17/2465.full.html\#ref-list-1

License

Email Alerting Receive free email alerts when new articles cite this article - sign up in the box at the top Service right corner of the article or click here.

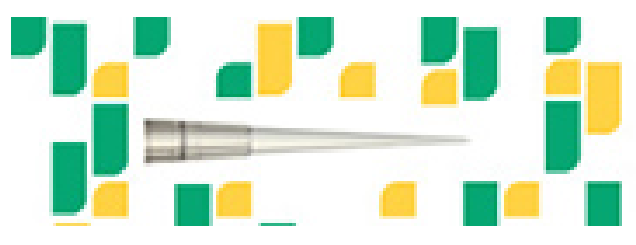

Focused on your science. 